\title{
EFFICACY OF HARIDRA KWATH KAWAL IN MANAGEMENT OF ACUTE TONSILLITIS
}

\author{
YADAV M. ${ }^{*}$, KADAM D. ${ }^{2}$, VALHAVANKAR C. ${ }^{2}$, DOLE R. ${ }^{2}$, BHADLIKAR D. ${ }^{1}$ \\ 1Dr D.Y. Patil Ayurved College, Hospital \& Research Center, Navi Mumbai- 400 706, MS, India. \\ ${ }^{2}$ Bharati Vidyapeeth University's College of Ayurved, Katraj, Pune- 411 043, MS, India. \\ ${ }^{*}$ Corresponding Author: Email- meena_ksy@rediffmail.com
}

Received: December 18, 2012; Accepted: December 27, 2012

\begin{abstract}
-
Aim and Objective: Tonsillitis is inflammation of the tonsils most commonly caused by a viral or bacterial infection whose symptoms include sore throat and fever. A modern medicine has faster relief but it has many side effects and produces toxins inside the body, it needs detoxification. Detoxification increases load on vital organs. Herbal preparation from Haridra (turmeric) has no side effects as compared with allopathic compounds.

Material and Methods: Patients in Shalakya Tantra OPD and IPD are recruited in this study after proper consent. Subjects in this study are grouped into trail group i.e acute tonsillitis and control group as healthy volunteers. Ethical guidelines of ICMR for human research are strictly followed. Haridra Kwath Kawal treatment is prescribed to the patients who are suffering from acute tonsillitis.

Results and Discussion: Patient attending clinic examined thoroughly, all sign and symptoms are recorded in patient information sheet. Treatment prescribed is explained to patient and its prognosis is recorded in prescribed format for various parameters on $1^{\text {st }}$ day, $3^{\text {rd }}$ day, $5^{\text {th }}$ day and $7^{\text {th }}$ day of treatment. All study data is analyzed by applying Mann Whitney $U$ test and significance $P$ value calculated for individual symptom.

Conclusion: It is concluded from this study that treatment with Haridra Kwath Kawal on Acute Tonsillitis relieves majority of symptoms and recovery of disease is fast. It is simplest method of treatment with minimal or no side effects. Due to its antibacterial and antiinflammatory property of Haridra, symptoms of acute tonsillitis relives without side effect. Haridra Kwath Kawal is proved scientific procedure for treatment of acute tonsillitis in Indian Medicine Science
\end{abstract}

Citation: Yadav M., et al (2012) Efficacy of Haridra Kwath Kawal In Management of Acute Tonsillitis. International Journal of Medical and Clinical Research, ISSN: 0976-5530 \& E-ISSN: 0976-5549, Volume 3, Issue 8, pp.-235-241.

Copyright: Copyright@2012 Yadav M., et al. This is an open-access article distributed under the terms of the Creative Commons Attribution License, which permits unrestricted use, distribution and reproduction in any medium, provided the original author and source are credited.

\section{Introduction}

According to Indian medicine literature, all oriental knowledge has its origin in Vedas. Vedas are regarded as the oldest scientific document in written form. Among the four Vedas Rugveda, Yajurveda, Samaveda and Atharvaveda. Ayurveda is Upaveda of 'Atharvaveda'. Ayurveda is not merely system of medicine in its conventional sense of curing disease but it is science of life. The word 'AYU' stands for life and word 'VEDA' stands for knowledge. Hence Ayurveda deals with every aspects of life.

The management of sore throat is a significant burden on health service resources. However, a significant number of patients experience unacceptable morbidity, inconvenience, and great loss due to recurrent sore throat. The use of antibiotics in patients with recurrent sore throat has been controversial. The indications for tonsillectomy have long been a matter of discussion. Tonsillectomy has a minor but significant complication rate and an outcome that is not clearly defined and that is the main purpose of this study.

Tonsillitis is inflammation of the tonsils most commonly caused by a viral or bacterial infection whose symptoms include sore throat and fever. The majority of patients recover completely with or without medication. In 40\%, symptoms have resolved in three days and within one week in $85 \%$, regardless of whether streptococcal infection (a common cause) is present or not [1].

Tonsillitis refers to inflammation of the pharyngeal tonsils. The inflammation may be at other areas of the back of the throat including the adenoids and the lingual tonsils (areas of tonsil tissue at the back of the tongue). Tonsils are small at birth, enlarge during childhood age, and become smaller at puberty. Tonsils normally help to prevent infection in the sinuses, mouth and throat from spreading to other parts of the body. Tonsillitis is contagious. It affects all ages, but is very common in children between ages 5 and 10.There is several variations of tonsillitis: acute, recurrent, and 
chronic tonsillitis and peritonsillar abscess.

Viral infection bacterial infection and immunologic factors are responsible for tonsillitis and its complications photographed in [Fig1]. Because of improvements in medical and surgical treatments, complications associated with tonsillitis, including mortality, are rare.

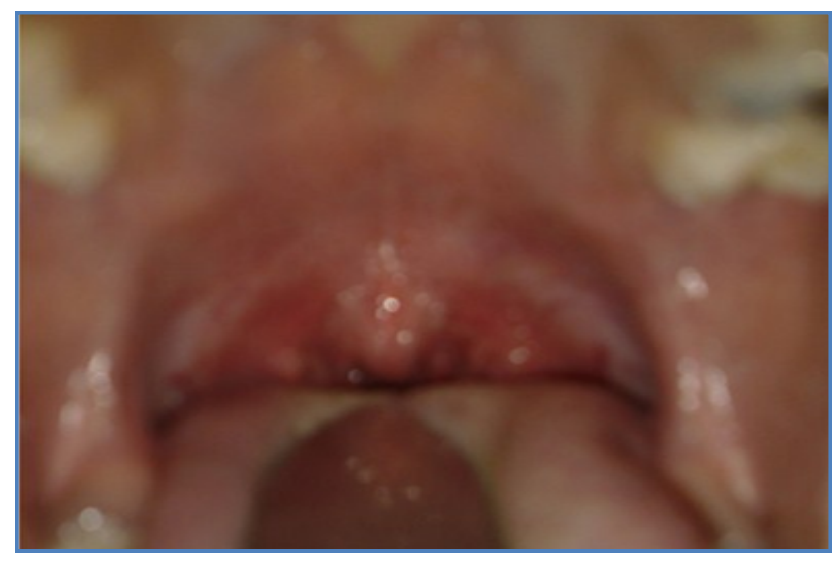

Fig. 1- Photograph of patient aged 10 years suffering with acute tonsillitis.

Tonsillitis is an inflammation of the Tonsil and most $f$ the time, but not always, cause a sore throat and fever. A ring of lymphoid tissue surrounds the naso-pharynx and oro-pharynx, these lymphoid tissues are collectively known as the waldayer's ring. The waldayer's ring has two components, inner and outer rings. The cervical lymph nodes constitute the outer ring, while the inner ring is constituted by;

i. Adenoid at the roof of Nasopharynx,

ii. Tubal tonsils or tonsil of Gerlac which surround the pharyngeal ends of Eustachian tube. These lymphoid tissues surround the naso-pharynx.

The lymphoid tissue surrounded by the oropharynx also constituting the components of the inner Waldayer's ring is;

i. Lingual tonsil in the posterior $1 / 3$ of the tongue,

ii. Palatine tonsils on either side of oropharynx, and

iii. Sub epithelial lymphoid tissue found in the posterior area of pharyngeal wall. All these structures of the inner Waldayer's ring are inter linked.

\section{Common Signs and Symptoms of Acute Tonsillitis Include}

Symptoms recorded during the peak of disease are sore throat, red swollen tonsils, headache pain while swallowing, fever with chills and coughing. Less common symptoms are nausea, stomach ache, vomiting, furry tongue, bad breath (halitosis), voice changes and difficulty opening the mouth (trismus) In cases of acute tonsillitis, the surface area of the tonsil may be bright red and with visible white areas or streaks of pus patches [6]. Tonsilloliths occur in up to $10 \%$ of the population frequently due to episodes of tonsillitis [2$5,7]$.

\section{Causes of Tonsillitis}

The most common causes of tonsillitis are the common cold virus- es. It can also be caused by Epstein-Barr virus, herpes simplex virus, cytomegalovirus (CMV), or HIV. The second most common cause is bacterial infection. The most common bacterial cause is Group A $\beta$-hemolytic streptococcus (GABHS), which causes strep throat. Less common bacteria which causes acute tonsillitis include: S. aureus, S. pneumoniae, Mycoplasma pneumoniae, Chlamydia pneumoniae, C. diphtheria, syphilis, and M. gonorrhea.

Under normal circumstances, as viruses and bacteria enter the body through the nostril and mouth cavity, they are filtered in the tonsils. Within the tonsils, white blood cells of the immune system attack helps to destroy the viruses or bacteria, and also causes inflammation and fever. The infection may also be present or spread in the throat and surrounding areas, causing inflammation of the pharynx. This is the area in the back of the throat that lies between the voice box and the tonsils.

Tonsillitis may be caused by Group A streptococcus, resulting in strep throat. Viral tonsillitis may be caused by some viruses such as the Epstein-Barr virus or adenovirus.

\section{Aims and Objectives}

1. To study the Tonsillitis

2. To study the efficacy of Haridra Kwath Kawal in Moderate Tonsillitis as a trail group.

3. To study efficacy of warm saline gargle in Moderate Tonsillitis as a control group.

Shalakya includes study of Shravana, Nayana,Vadana, Ghrana and all organs situated superior to Jatru (Clavicle). Mukh/ Vadana are a broad concept. Opinion of Yogaratnakar, it includes Oshtha, Danta, Dantamoola, Jivha, Talu and Gala. Gala is very important organ as far as Moderate Tonsillitis disease is concern.

\section{Material and Methods}

Single blind randomized study designed 30 patients in each group. In Group ' $A$ ' 30 patients with one or more symptoms of Moderate Tonsillitis were taken in Trail group who receives Haridra Kwath Kawal treatment and Group 'B' 30 patients in Control group who receives Warm Saline Gargle. Duration of treatment is 7 days.

\section{Review and Literature}

Turmeric has been used in the Indian System of medicine since ancestral time. It is also listed in an Assyrian herbal dating from about $600 \mathrm{BC}$.

In Indian systems of medicine, turmeric is used to some extent as a stomachic tonic and blood purifier. Mixed with warm milk it is said to beneficial in common cold. The crushed juice of the fresh rhizome is used as an anti-parasitic for many skin infections. Externally, it is applied to wounds or ulcers, and a paste made from the powdered rhizome along with lime forms a remedy for swelling or inflamed joints. Oil of turmeric, distilled from the dried rhizomes, has antiseptic properties. It is an antacid and, in small doses, acts as a carminative, appetizer and tonic. In large doses, (2-4 c.c. of concentrated solution), however, it appears to act as an antispasmodic, inhibiting excessive peristaltic movements of the intestines [8]. Both East and West have held its medicinal properties in high regard. It is reported to be tonic, blood purifier, antacid, and 
carminative. Turmeric boiled in milk is given for sore throat, throat infection and common colds. The paste of turmeric is also externally applied on skin surfaces affected by ringworm, scabies and eczema. It is a skin tonic because of anti-oxidant property and improves skin complexion. It is also claimed to have curative properties for infections of the liver and gall bladder. An Ayurvedic eye drop, Haridra, containing turmeric was subjected to clinical trials with patients suffering from conjunctivitis and it proved very effective in controlling the infection. Turmeric is a valuable styptic and its lotion is applied to small pox or chicken pox eruptions. The alcoholic extract showed antibacterial activity. In Kumaon hills, a paste of the dry powdered rhizome is applied to swellings, insect stings and wounds. Inhalation of the fumes from burning turmeric is recommended in nasal infection and for neurological disorders. It is also used in asthma, bronchitis and fever. Turmeric powder boiled with milk is used for the treatment of cough and dyspnea shows great improvement [9-19].

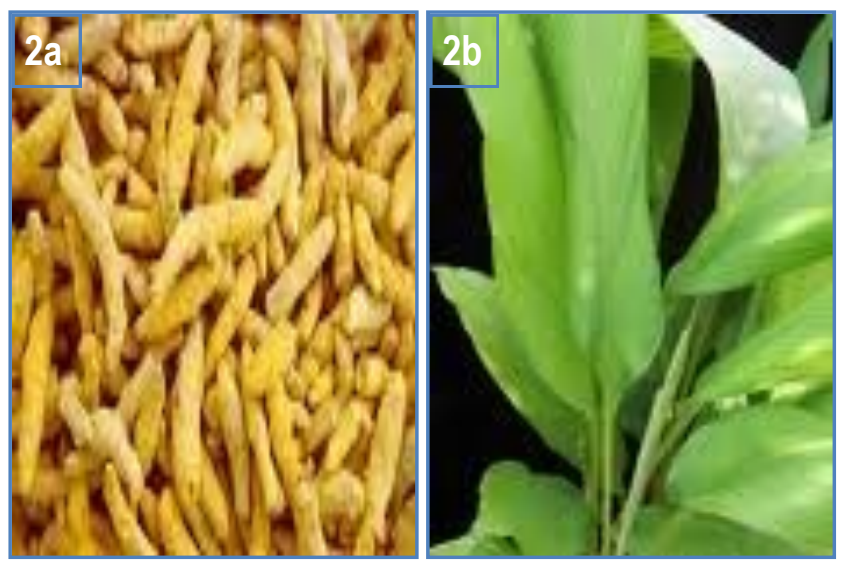

Fig. 2- Haridra (Curcuma longa Linn.) Kand and its plant

Botanical Name- Curcuma longa Linn. (Curcumadomestica Valeton). The physical appearance of Haridra (Curcuma longa Linn.) Kand \& its plant is shown in [Fig-2a] and [Fig-2b].

Family- Zingiberaceae, Turmeric was described as Curcuma longa by Linnaeus and its taxonomic position is as follows

$\begin{array}{ll}\text { Class } & \text { Liliopsida } \\ \text { Sub-class } & \text { Commelinids } \\ \text { Order } & \text { Zingiberales } \\ \text { Family } & \text { Zingiberaceae } \\ \text { Genus } & \text { Curcuma }\end{array}$

Species Curcuma Longa

The wild turmeric is called Curcuma aromatica and the domestic species is called Curcuma longa.

\section{Sanskrit Synonyms}

$$
\begin{gathered}
\text { हरिद्राकाज्चनी पी तानिशाख्या वरवर्णिनी। } \\
\text { कृमिघ्नाहलनदी याष्त्रियाहटृवित्नासिनी।। } \\
\text { सू. }
\end{gathered}
$$

Harida, Kanchanee, Peeta, Nisha, Nishakhya, Vuravarnini, Krimighna, Haldi, Yoshitpriya, Hattavilasinee.

\section{Gana}

According to Charaka- Kushthgna, Kandugna, Vishgna, Tiktaskandha, Shiro-virechana.

According to Sushruta- Haridradi, Mustadi, Sleshma, Prashaman.

\section{Types of Haridra}

Haridra- Curcuma longa Linn.,

Karpuraharidra or Amraharidra- Curcuma amada,

Vanaharidra- Curcuma aromatic,

Daruharidra- Berberis species.

\section{Botanical Description}

A tall herb, rootstock large, ovoid with sessile cylindrical tubers and orange colored inside. Leaves are very large, in tufts up to 1.2 meter or more, including the petiole which is about as long as blade, oblong- lanceolate, tapering to the base. Flowers in autumnal spikes $10-15 \mathrm{~cm}$ long, Peduncle $15 \mathrm{~cm}$ or more, concealed by the sheathing petiole, flowering bracts pale green, bracts of coma tinged with pink. It is useful in "Kapha and vata", disease of blood, leucoderma, scabies, and bad test in mouth, dyspepsia, and swelling. The rhizomes externally applied in pain.

The root perched and powdered, is given in bronchitis. Turmeric and alum in the proportion of 1:20 is blown into the ear in chronic otorrhoea.

\section{Names of Haridra (Turmeric) in Various Languages \\ Arabic- Aurukesafur, Kurkum, Urukessabaghin, Urukessubr, Bengal- Haldi, Pita \\ English- Indian saffron, Turmeric \\ French- Curcuma, Kurkum \\ Hindi- Haldi \\ Italian- Curcuma, Kshapa, Lakshmi \\ Tamil- Manjal \\ Telugu- Pampi, Pasupu \\ Urdu- Haldi.}

Root- Ovoid, sessile, tubers thick, cylindrical, light yellow inside.

Leafy tuft $1.0-1.5 \mathrm{~m}$, petiole as long as the blade.

Peduncle $1.5 \mathrm{~m}$ or more, hidden by the sheathing petiole.

Flowers- incensed compound spikes crowned by coma of colored enlarged bracts; lower bracts ovate, membranous, enclosing several bracteolate fugitive flowers which open in succession. Spikes 10-12 cm long, $5 \mathrm{~cm}$ diameter, flower bracts pale green, those of the coma tinged with pink; flowers are as long as bracts and pale yellow.

Calyx- short, cylindrical, sepals' free and imbricate, whitish, obtusely toothed. Corolla tube funnel shaped. 
The reason for this is that gargle solution has only a limited time of patient tolerability. Patient can keep solutions in their oral cavities for limited time frames, usually counted in terms of 20-30 seconds, before they feel the need to expel them

In the case of sodium chloride gargles, for example, gargling will rapidly stimulate and irritate the receptors within the throat that will induce expulsive reflexes.

Sodium chloride solution, in addition, requires sufficient time of exposure to perform their anti-inflammatory, bacterio-static, bactericidal, and anti-fungal actions. Gargling alone cannot achieve this task since the required time for effective sodium chloride exposure ranges from several minutes to an hour.

Dose- Once a day in early morning \& at time $250 \mathrm{ml}$ (glass full) warm saline water. Purified salt which is domestically used for cooking is used for this purpose. With respect to sore throat, a sense of fullness and difficulty swallowing are both related to edema of the throat. If the gargle has a higher salt concentration (normally $2 \%$ ) than your cells' salt concentration which is $1 \%$ same as normal saline, it will tend to draw out some of the edematous fluid from the mucosa of the throat. This may relieve your sore throat symptoms in some extent. The relief is short-lived, since the worm saline ( $40^{\circ}$ to $45^{\circ}$ Celsius) gargle has done nothing to remove the cause of the sore throat.

\section{Results}

After proper examination clinical symptoms are recorded in patient's case paper. After the fulfillment of criteria, consent in written is taken from the patient on the 1 st day of registration in OPD. Pediatric age patients photograph with acute tonsillitis is taken [Fig-6a] for comparison. All benefits \& pitfalls of this study is explained to the patient prior to start the treatment of Haridra Kwath Kawal. Case history and follow-up findings are recorded in case paper on $3^{\text {rd }}, 5^{\text {th }}$ and $7^{\text {th }}$ day of treatment.

Symptoms of moderate tonsillitis followed by treatment of Haridra Kwath kawal are recorded as per gradation given above from $1^{\text {st }}$ day of treatment to last day of treatment [Fig-6b].

Patient's symptoms are graded if Normal graded for ' 0 ', Mild graded for ' + ', Moderate graded for '++', and Severe graded for '+++'.
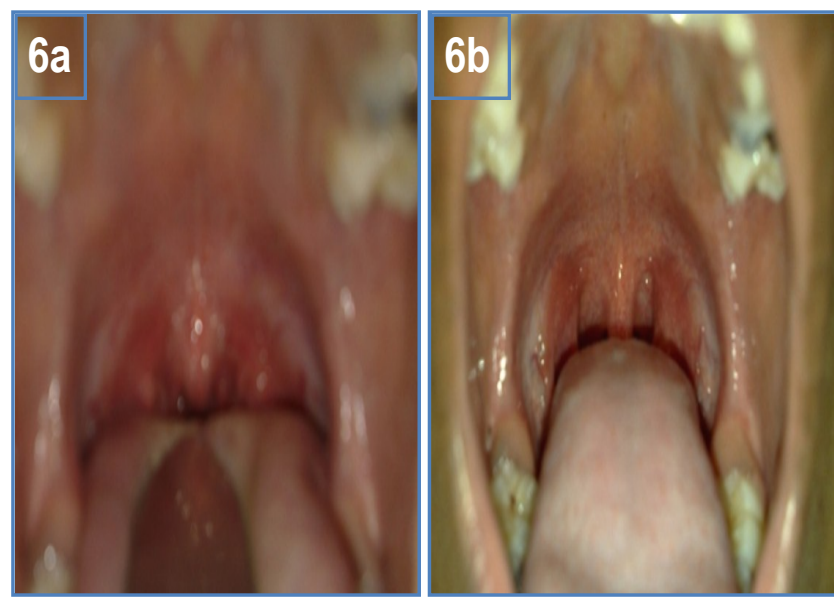

Fig. 6- Photograph of Acute tonsillitis before treatment and after treatment with Haridra Kwath Kawal.

\section{Statistical Analysis}

Statistical Analysis of data shows that in Trail group 28(93.33\%) patients are between $10-35$ years age \& $2(6.66 \%)$ patients are from 36-60 year group. In Control group all 30(100\%) patients are between 10-35 years age group only. Gender wise distribution of subjects in trail group are10 Male \& 20 female. In Control group 15 patients are Male \& 15 are female in [Fig-7a] and [Fig-7b].
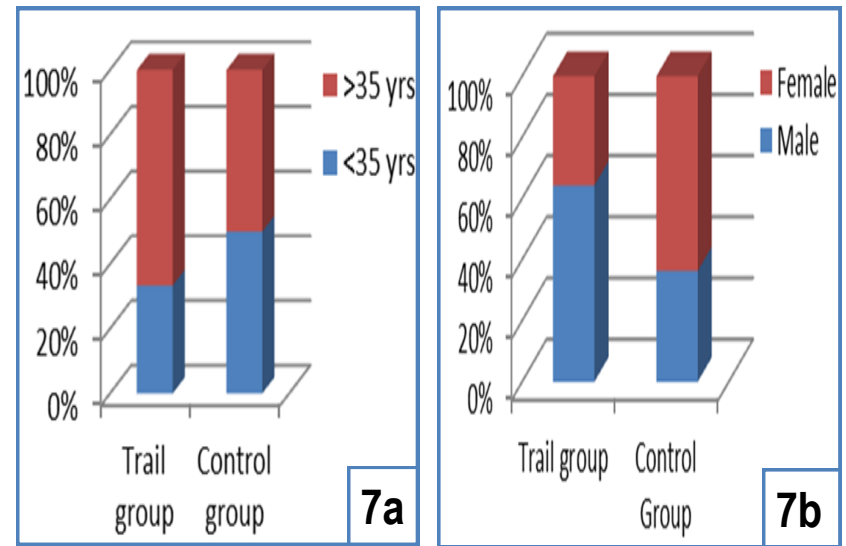

Fig. 7- Bar diagram presents age wise and gender wise distribution of patients in trail and control group.

In trail group symptom wise analysis shows that $21(69.99 \%)$ patient reported throat inflammation, from which 7are Male $(33.33 \%)$ \&14 are female $(66.66 \%)$. Total $30(100 \%)$ patient reported throat pain, 9 are male $(29.99 \%) \& 21$ female $(70.01 \%)$. Total 06 $(19.99 \%)$ patient reported Fever, 3 are Male $(50 \%) \& 3$ are female $(50 \%)$. Total $18(59.99 \%)$ patient reported Cough, 5 are Male $(27.77 \%) \& 13$ are female $(72.23 \%)$. Total10 $(33.33 \%)$ patient reported Change of Voice, 2 are Male $(20 \%) \& 8$ female (80\%) and total $3(10 \%)$ patient reported due to Ear ache (Otalgia), 2 are Male $(66.66 \%) \& 1$ female $(33.33 \%)$. Headache is recorded only in female patient not in male, reason is unknown, otherwise it may be co-incidence [Fig-8].

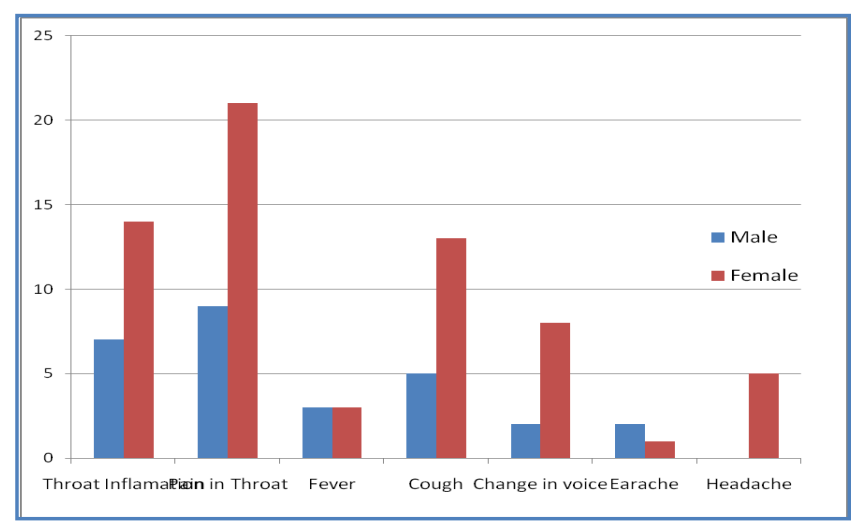

Fig. 8- Symptom wise distribution of patient's data in bar diagram

\section{Mann Whitney U Test}

Study data is analyzed by applying Mann Whitney $U$ test (also called the Mann Whitney Wilcoxon (MWW) or Wilcoxon rank-sum test).

Although non-normal data are widespread in biomedical research, parametric tests unnecessarily, predominate in statistical analyses. 
Various five biomedical journals were surveyed and for all studies which contain at least the unpaired t-test or the non-parametric Wilcoxon and Mann-Whitney $U$ test -investigated the relationship between the choice of a statistical test and other variables such as sample size, randomization etc. The non-parametric test was more common in case of non-continuous data, in high-impact journals, in studies in humans, and when the statistical software is specified, in particular when SPSS was used [20].

\section{Discussion}

Treatment of acute tonsillitis is continuous process. While going through publications and granthas on Ayurveda medicines, reviewed different various research work on Moderate Tonsillitis.

Symptoms of disease and its prognosis are recorded on $1^{\text {st }}$ day, $3^{\text {rd }}$ day, $5^{\text {th }}$ day and $7^{\text {th }}$ day. Haridra is having properties of antiinflammatory and anti-bacterial activity. Haridra Kwath Kawal treatment for acute tonsillitis shows significant improvement on Inflammation in Throat. Mild improvement is seen on $3^{\text {rd }}$ day of follow-up. It has reported that moderate and significant improvement on $5^{\text {th }}$ and $7^{\text {th }}$ day of follow-up subsequently.

Haridra Kwath Kawal treatment for acute tonsillitis shows significant improvement in the symptoms of pain in throat while swallowing. Mild improvement is recorded on $3^{\text {rd }}$ day of follow-up. It has been reported that moderate and significant improvement on $5^{\text {th }}$ and $7^{\text {th }}$ day of follow-up subsequently.

Haridra (Curcuma longa Linn.) is a unique bactericidal, antiinflammatory and anti-viral agent. It possesses anti-inflammatory properties and has a well-known safety profile when applied topically. Haridra Kwath Kawal treatment for acute tonsillitis shows moderate improvement in the symptoms of change of voice. Mild but non-significant improvement is recorded on $3^{\text {rd }}$ day of follow-up. It has been reported that moderate improvement on $5^{\text {th }}$ and $7^{\text {th }}$ day of follow-up subsequently.

Fever is mostly associated with throat infection in tonsillitis. Haridra Kwath Kawal treatment for moderate tonsillitis shows moderate improvement in the symptoms of fever. Mild but non-significant improvement is recorded on $3^{\text {rd }}$ day of follow-up. It has been reported that moderate improvement on $5^{\text {th }}$ and $7^{\text {th }}$ day of follow-up subsequently.

Cough is mostly associated with throat infection in tonsillitis either bacterial or viral. Since Haridra (Curcuma longa Linn.) is a bactericidal, anti-inflammatory and anti-viral agent, Haridra Kwath Kawal treatment for acute tonsillitis shows significant improvement in the symptoms of cough. Mild improvement is recorded on $3^{\text {rd }}$ day of follow-up. It has been reported that moderate and significant improvement on $5^{\text {th }}$ and $7^{\text {th }}$ day of follow-up subsequently [Table-1].

Table 1- Mann Whitney $U$ test between trail and control group for all symptoms and its t paired ( $P$ value)

\begin{tabular}{lcccc|} 
Symptoms & $1^{\text {st }}$ day & 3rd day & $5^{\text {th }}$ day & $7^{\text {th }}$ day \\
Throat inflammation & 0 & 0.03 & 0.45 & 0.001 \\
Pain while swallowing & 0 & 0.69 & 0.5 & 0.02 \\
Fever with Chills & 0.31 & 0.27 & 0.15 & 0.77 \\
Cough & 0.7 & 0.37 & 0.24 & 0.55 \\
Change of Voice & 0.21 & 0.45 & 0.39 & 0.07 \\
Otalgia & 0.35 & 0.44 & 0.52 & 0.09 \\
Headache & 0.05 & 0.05 & 0.03 & 0.03 \\
\hline
\end{tabular}

Ear, Throat and Nose (ENT) they are inter-connected to each other. In acute tonsillitis, due to bacterial or viral infection, inflammation occurs. Thus irritation in throat causes pain in Ear. Since Haridra (Curcuma longa Linn.) is a bactericidal, anti-inflammatory and anti-viral agent, Haridra Kwath Kawal treatment for acute tonsillitis shows significant improvement in the symptoms of earache. Mild improvement is recorded on $3^{\text {rd }}$ day of follow-up. It has been reported that moderate and significant improvement on $5^{\text {th }}$ and $7^{\text {th }}$ day of follow-up subsequently [Table-2].

Table 2- Effect of treatment \& percentage of improvement of Haridra Kwath Kawal for trail group is calculated for $3^{\text {rd }}, 5^{\text {th }}$ and $7^{\text {th }}$ day of treatment, which is given in following table

\begin{tabular}{lccc|}
\hline \multirow{2}{*}{ Symptoms } & \multicolumn{3}{c}{ Effect of Haridra Kwath Kawal in \% } \\
& 3rd Day & 5 th Day $^{\text {th }}$ & 7 \\
Inflammation in Throat & $44 \%$ & $76 \%$ & $92 \%$ \\
Pain in throat & $48 \%$ & $72 \%$ & $86 \%$ \\
Change of Voice & $23 \%$ & $41 \%$ & $62 \%$ \\
Fever & $15 \%$ & $26 \%$ & $39 \%$ \\
Cough & $25 \%$ & $40 \%$ & $53 \%$ \\
Otalgia & $18 \%$ & $29 \%$ & $42 \%$ \\
Headache & $13 \%$ & $24 \%$ & $35 \%$ \\
\hline
\end{tabular}

Haridra (Curcuma longa Linn.) is bactericidal, anti-inflammatory and anti-viral agent. It possesses anti-inflammatory properties and has a well-known safety profile when applied topically. Haridra Kwath Kawal treatment for acute tonsillitis shows moderate improvement in the symptoms of headache. Mild but non-significant improvement is recorded on $3^{\text {rd }}$ day of follow-up. It has been reported that moderate improvement on $5^{\text {th }}$ and $7^{\text {th }}$ day of follow-up subsequently.

\section{Conclusion}

It is concluded from this study that treatment with Haridra Kwath Kawal on acute Tonsillitis relieves majority of symptoms and recovery of disease is fast. It is simplest method of treatment with minimal or no side effects. Herbal material used in this treatment Haridra (Curcuma longa Linn.) is easily available. Due to its antibacterial and anti-inflammatory property symptoms of acute Tonsillitis relives without side effect. Kawal proved important procedure for treatment of Tonsillitis in Mukhroga.

\section{References}

[1] Del Mar C.B., Glasziou P.P., Spinks A.B. (2006) Del Mar, Chris B. ed., 18(4).

[2] Bonita F. Stanton, Kliegman Robert, Nelson Waldo E., Behrman Richard E., Jenson Hal B. (2007) Nelson Textbook of Pediatrics.

[3] Wetmore R.F. (2007) Kliegman: Nelson Textbook of Pediatrics.

[4] Thuma P. (2001) Primary Pediatric Care, 4th ed., 1744-1747.

[5] Simon H.B. and David (2005) ACP Medicine.

[6] John P. Cunha (2010) Tonsillitis and Adenoid Infection, Medicine Net.

[7] Nour S.G., Mafee Mahmood F., Valvassori Galdino E., Galdino E. Valbasson, Minerva Becker (2005) Thieme, 716.

[8] Chopra, et al. (1941) Indian J. Med. Res., 29, 769.

[9] Bone K. (1991) Brit. J. Phytother., 2(2), 51. 
[10]Goh and $\mathrm{Ng}$ (1987) Contact Dermatitis, 17, 186.

[11]Lahiri (1980) East Pharm., 23(243), 25.

[12]Lahiri (1984) Fmrs' J., 4(6), 34.

[13]Kapur (1991) Indian Drugs, 28, 210.

[14]Sathyl J. (1983) Nat. Integr. Med. Assoc., 25, 357.

[15]Uhe (1974) Econ. Bot., 28, 7.

[16]Srinivas and Prabhakaran (1988) Ancient Sci Life, 8, 279.

[17]Shah and Joshi (1971) Econ. Bot., 25, 413.

[18]Nagata (1971) ibid, 25, 245.

[19]Jain, et al (1979) J. Res. Indian Med. Yoga, 14 (2), 110.

[20]Okeh U.M. (2009) Biotechnology and Molecular Biology, 4(6), 128-131. 